
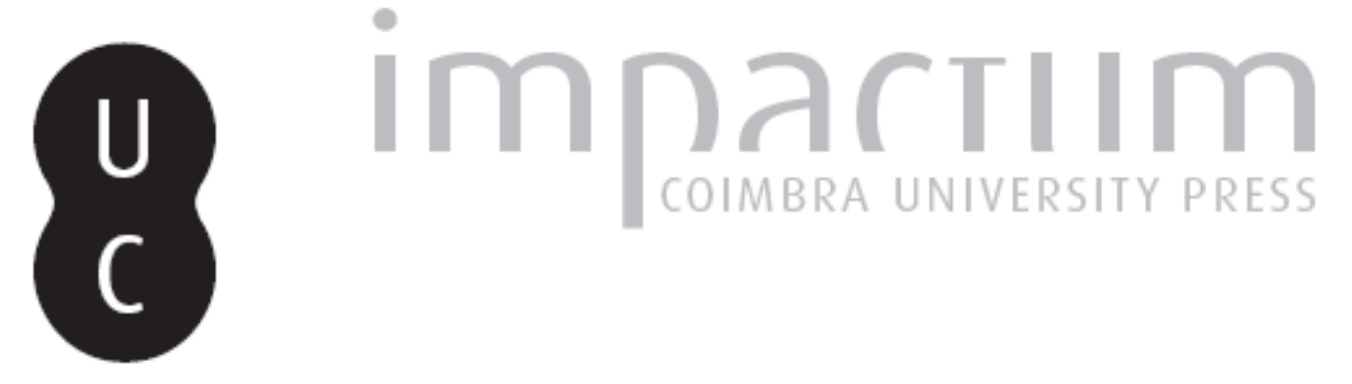

In the intimacy of thought: Darwin's notebooks on the moral sense of man

Autor(es): Costa, Palmira Fontes da

Publicado por: CIAS - Centro de Investigação em Antropologia e Saúde

URL persistente:

URI:http://hdl.handle.net/10316.2/28682

DOI:

DOI:http://dx.doi.org/10.14195/2182-7982_27_8

Accessed : $\quad$ 26-Apr-2023 12:35:52

A navegação consulta e descarregamento dos títulos inseridos nas Bibliotecas Digitais UC Digitalis, UC Pombalina e UC Impactum, pressupõem a aceitação plena e sem reservas dos Termos e Condições de Uso destas Bibliotecas Digitais, disponíveis em https://digitalis.uc.pt/pt-pt/termos.

Conforme exposto nos referidos Termos e Condições de Uso, o descarregamento de títulos de acesso restrito requer uma licença válida de autorização devendo o utilizador aceder ao(s) documento(s) a partir de um endereço de IP da instituição detentora da supramencionada licença.

Ao utilizador é apenas permitido o descarregamento para uso pessoal, pelo que o emprego do(s) título(s) descarregado(s) para outro fim, designadamente comercial, carece de autorização do respetivo autor ou editor da obra.

Na medida em que todas as obras da UC Digitalis se encontram protegidas pelo Código do Direito de Autor e Direitos Conexos e demais legislação aplicável, toda a cópia, parcial ou total, deste documento, nos casos em que é legalmente admitida, deverá conter ou fazer-se acompanhar por este aviso.

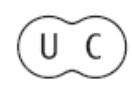




\section{Antropologia Portuguesa}

Volume $26-27 \cdot 2009-2010$

Departamento de Antropologia | Universidade de Coimbra

DARWINISMO:

revisitações, propostas, problemas 


\title{
In the intimacy of thought: Darwin's notebooks on the moral sense of man
}

\author{
Palmira Fontes da Costa \\ Universidade Nova de Lisboa, Portugal \\ pfc@fct.unl.pt
}

Resumo Com o saber de que nós, tal como os outros seres vivos, pertencemos a uma espécie que evoluiu através da selecção natural, vem o reconhecimento de que os processos evolutivos nos marcaram profundamente. No entanto, até que ponto? Darwin admitiu que, de todas as diferenças entre o Homem e os outros animais, o sentido moral é, de longe, a mais importante. Poderá esta faculdade especificamente humana reflectir a nossa herança evolucionista? A resposta afirmativa de Darwin a esta questão apenas seria publicada em 1871 na obra The Descent of Man. No entanto, as suas primeiras reflexões sobre o problema são bastante anteriores e acompanharam o esboço das suas ideias transformistas. Tendo como base alguns dos cadernos de notas de Darwin, este artigo analisa o rasto e a dinâmica do seu pensamento a propósito da questão crucial da existência de um sentido moral próprio ao ser humano. Esta documentação de índole pessoal permite inferir quais foram os pensadores que mais marcaram o famoso naturalista, que problemas nortearam o seu pensamento, quais foram algumas das inflexões e estratégias que assumiram maior destaque no delinear do seu pensamento a propósito desta temática com implicações filosóficas e biológicas.

Palavras-chave Ética; evolução; ser humano; inato; altruismo; consciência.

Summary With the recognition that we, like all living beings, belong to a species that has evolved through natural selection, comes the acknowledgement that evolutionary processes have shaped us profoundly. But how profoundly? Darwin acknowledged that of all the differences between man and the lower animals, the moral sense or conscience is by far the most important. Could this specific human faculty reflect our evolutionary heritage? Darwin's affirmative answer to this question was only published in 1871 in his work The Descent of Man. However, his first thoughts on the problem date from much further back and accompanied his early ideas on the transformation of species. This article analysis Darwin's notebooks on the moral sense of man. These personal documents enable us to know who were the philosophers that influenced him more on such a fundamental question, what were the problems and obstacles that concerned him more as well as what were the thought leaps and patterns that he took in order to better answer a subject that had implications at both a philosophical and biological level.

Key words Ethics; evolution; human being; innate; altruism; conscience. 
Society could not go on except for the moral sense, any more than a hive of bees without their instincts.

C. Darwin, Old \& useless notes about the moral sense \& some metaphysical points

Despite his mysterious illness, Charles Darwin (1809-1882) lived a good and long life. He had the chance to devote his time entirely to his research and family and, as we know, he was very prolific in terms of both children and original publications. He also left behind a vast amount of correspondence (still in the process of being published) that he established with various friends and colleagues over the years. During his voyage on the Beagle, Darwin annotated his observations in small notebooks. He retained this habit after returning to England.

Darwin's notebooks provide a fascinating and delightful reading of Darwin's mind in uncensored action. In opposition to the cautious and public naturalist, the young, private Darwin is revealed in bold spontaneity. The notebooks offered secret freedom. Freedom for questions, doubts, suspicions, statements or mere annotations on what others had written. In them, we find questions as fundamental as the origin of beauty or the pleasure of music: "What is beauty? - it is an ideal standard, by which real objects are judged: $\&$ how obtained-implanted in our bosoms-how comes it there?" (Darwin, Old and Useless Notes: 22); "Did our language commence with singing - is this origin of our pleasure in music?" (Darwin, Notebook N: 18). We can also discover crucial doubts on the "separation between [the] soul of man \& [the] intellect of beasts" (Darwin, Old and Useless Notes: 21). Additionally, we learn of his ironic definition of science as "reason acting systematizing on principles, which even animals practically know" (Darwin, Old and Useless Notes: 14) or his injunction against metaphysics which seemed to have always been studied "like puzzling at Astronomy without Mechanics. - Experience shows the problem of the mind cannot be solved by attacking the citadel itself. - the mind is function of body" (Darwin, Notebook N: 5). At times, the young Darwin makes ostentatious declarations. In one of the notebooks he exclaims that the "origin of man now proved. - Metaphysic must flourish. - He who understands baboon would do more towards metaphysics than Locke" (Darwin, Notebook M: 84).

While perusing Darwin's notebooks, it is also difficult not to note his frequent references to dogs. This is not surprising, since his love for this 
animal was "a passion" and, as he remarked in his Autobiography, they "seemed to know this, for I was an adept in robbing their love from their masters" (Darwin, 1887: 30). Darwin's fondness for dogs provided him with an opportunity for various observations on their instinct, behavior and expressions that would be useful for his work as a naturalist. From the notebooks we learn, among other things, that "Man \& dogs show triumph (\& pride) same way walk erect \& stiff, with head up" (Darwin, Notebook N: 7); "I suspect very strong argument might be advanced, that animals have reason, because they have memory - what use this faculty if not reason. or does this reasoning apply chiefly to recollection, yet a dog hunting for a bone shows he has recollection" (Darwin, Notebook N: 90). "When a dog in play has his mouth open ready to bark, \& lip twisted up, in that peculiar manner they do, even more than in a real snarl, they are enjoying a satirical, laugh.- when snarling real bitter sarcasm" (Darwin, Notebook N: 92); "dogs have notion of masters property" - is not this rather more friendship [?]" (Darwin, Notebook N: 126).

It was in the Transmutation Notebooks that Darwin first sketched his theory on the origin of species by means of natural selection. The first notebook of this series was opened in July 1837 and labeled "B" (his "A" notebook was mostly concerned with geology). For the first time, on page 36, Darwin conceived of life as a branching three. He thus began two years of secret telegraphic annotations on the mechanism of species change. More or less at the same time, Darwin began two notebooks where, among other topics, he reflected on the origin of the moral sense of man. One of them was labeled Old \& useless notes about the moral sense \& some metaphysical points. It was written around the year 1837 and earlier. Notebook $M$ is "full of Metaphysics on Morals \& Speculations on Expression" and was written between 1838 and 1839. In addition, in Notebook N, dealing with Metaphysics and Expression, Darwin included a few considerations on the development and meaning of conscience in man written around the same period.

The three notebooks reveal the wide readings of Darwin on a variety of subjects and, in particular, on ethics. They comprise references to and quotations from a vast array of works and authors. Old \& Useless Notes alone makes reference to John Abercrombie (1780-1844), Jeremy Bentham (1748-1832), Joseph Butler (1692-1752), Samuel Taylor Coleridge (1772-1834), David Hartley (1705-1757), David Hume (1711-1776), Immanuel Kant (1724-1804), John Locke (1632-1704), James Mackintosh (1765- 
-1832), William Paley (1743-1805), Lord Shaftesbury (February 16711713), and William Whewell (1794-1866). Darwin was certainly eclectic and knowledgeable, but what accounts for his interest in ethics while he was developing his thoughts on the transmutation of species? How did the naturalist approach this philosophical subject?

Darwin's biographers stress that he was a kind and generous man (Browne, 1995; 2002). His upbringing awakened him to the moral environment through which he passed. His father provided him with an example of an honest, just, yet compassionate physician to rich and poor alike. He came from an abolitionist family. Not only were his parents and sisters in favour of the emancipation of slaves, but also his two famous grandfathers Erasmus Darwin and Josiah Wedgwood. During his Beagle voyage (1831-36), Darwin saw the worst excesses of slavery for himself and he was revolted by its "heart-sickening atrocities" (Darwin, 1839 in Desmond and Moore, 2010: 1). During his voyage, Darwin was not only shocked by slavery, he was also outraged by the Spanish troops who slaughtered whole Indian tribes (Darwin, 1933: 171). At the same time, he recognized that natives, although capable of moral courage, were also capable of great refinements of cruelty (Darwin, 1933: 98). Moreover, Darwin noticed that different societies could have distinctive codes of behavior, but that even within this diversity there are common attitudes about right and wrong conduct (Richards, 1987: 111).

Thus, the problem of morals had been one of the subjects of reflection for the young Darwin during his voyage on the Beagle but this was not the end of the story. When Darwin started working on his transmutation theory, the naturalist also felt the need to explore the origin of the moral sense. In order to avoid creationism, Darwin knew that it was imperative to provide a naturalist explanation of morality or ethics. Indeed, the admission of a divine source for ethical behavior would be a breach for creationist views. Therefore, Darwin did not only want to understand better the various theories of ethics, he was beginning to want to propose one of his own.

Notebook M and Old and Useless Notes show that James Mackintosh's Dissertation on the Progress of Ethical Philosophy (1836) was the most influential work on Darwin's understanding of the origin of the moral sense. They contain several quotations from the work as well as reflections on Mackintosh's thought. Mackintosh was a philosopher that Darwin knew from his family circle. In fact, he was the brother-in-law of Darwin's uncle, Josiah Wedgwood, ("uncle Jos") and, like the nephew, he frequently visited 
the Wedgwood country house at Maer. Darwin first met him in 1827 and, in his Autobiography, he recalled that he "listened with much interest to everything he [Mackintosh] said, for I was as ignorant as a pig about the subject of history, politicks and moral philosophy" (Darwin, 1887: 66).

According to Mackintosh, all of the fundamental controversies in modern ethical philosophy were initiated by Thomas Hobbes (1588-1679) in his book Leviathan (1651). While Aristotle (384-322 B.C.) had maintained that human beings are by nature social and political animals, Hobbes had argued that human beings are by nature asocial and amoral beings. Mackintosh criticized Hobbes and insisted that human nature comes equipped with a moral faculty for right conduct, an idea that promptly attracted the young naturalist. Thus, unlike most ethical philosophers, Mackintosh did not considerer moral action as being motivated by reason. Instead, he remarked that man gave spontaneous approval to virtuous acts since he promptly tried to assure the well-being of his children and naturally despised cowardice and meanness. That is, human beings could act altruistically for the good of others. In addition, and in opposition to British empiricists, Mackintosh proposed that a certain kind of knowledge was innate to man. The moral faculty would be enabled by this sort of intrinsic knowledge.

Mackintosh recognized that external circumstances such as "education, imitation, general opinion, laws and government" were also important in the development of the moral faculty (Mackintosh, 1862: 219). They could contribute to explaining variations in the moral conduct of different societies. Nevertheless, he argued that social processes of learning were insufficient to explain immediate responses to particular feelings of obligation.

As Robert J. Richards has shown, Darwin aimed to provide, in natural-historical and evolutionary terms, an interpretation of the faculties and relationships he found described in Mackintosh's Dissertation on the Progress of Ethical Philosophy (Richards, 1987: 116). The author's notion of the existence of innate knowledge found support in Darwin's observations of animals. As Darwin noted, "there is much knowledge without experience. So there may be in men" (Darwin, Old and Useless Notes: 33). Yet, where might he locate the biological roots of the moral sense? His first suggestion was that the moral sense was not only innate, as Mackintosh and other philosophers had argued, but also instinctive. Darwin traced two general kinds of instincts: impulsive instincts or passions, which he defined as emotional, strong and rapid responses, such as those caused by starvation 
and rage. Others were social instincts, which he considered not so immediate but as having a more lasting and influential effect in the long term. These instincts could conflict with each other such as, for example, when "in a dog we see a struggle between its appetite, or love of exercise \& its love of its puppies" (Darwin, Old and Useless Notes: 43). However, he thought that social instincts would invariably triumph in this confrontation.

Furthermore, Darwin noted that the social instincts of animals and the moral acts of men had the identical qualities of being innate, disinterested, and socially unifying. Thus, he argued that "the change in our moral sense is strictly analogous to change of instinct amongst animals" (Darwin, Old and Useless Notes: 30$)$. He detailed the reasons for this in the following terms:

"Looking at Man, as a Naturalist would at any other Mammiferous animal, it may be concluded that he has parental, conjugal and social instincts, and perhaps others.- The history of every race of man shows this, if we judge him by his habits, as another animal. These instincts consist of a feeling of love or benevolence to the object in question. Without regarding their origin, we see in other animals they consist in such active sympathy that the individual forgets itself, \& aids \& defends \& acts for others at its own expense" (Darwin, Old and Useless Notes: 42).

In addition, Darwin proposed that the social instincts of the individual tended to coincide with the criterion of utility - the greatest good for the greatest number - because only those instincts that generally benefited past generations would be inherited (Darwin, Old and Useless Notes: 51). This solved the problem of the distinction between the moral sense for right or wrong and the criterion of moral behaviour which had already been noted by Mackintosh: "If moral approbation involve no perception of beneficial tendency, whence arises the coincidence between that principle and the moral sentiments?" (Mackintosh, 1862: 332).

On the $2^{\text {nd }}$ October, 1838 , Darwin proudly stated his definitive view on morals:

"Two classes of moralists: one says our rule of life is what will produce the greatest happiness.- The other says we have a moral sense.-But my view unites both /\& shows them to be almost identical/ \& what has produced the greatest good /or rather what was necessary for good at all/is the /instinctive/ 
moral sense... In judging of the rule of happiness we must look far forward $/ \&$ to the general action/- certainly because it is the result of what has generally been best for our good far back" (Darwin, Old and Useless Notes: 30).

But why would the moral sense derive from social instincts in man and not in other social animals? In Notebook $M$, Darwin suggests that one crucial feature is the fact that man has a mind larger than that possessed by animals:

"May not moral sense arise from our enlarged capacity yet being obscurely guided or strong instinctive sexual, parental \& social instincts, giving rise "do unto others as yourself", "love thy neighbour as thyself". Analyse this out. - bearing in mind many new relations from language.- the social instinct more than mere love.-fear for others acting in unison.-active assistance" (Darwin, Notebook M: 150-151).

What an animal with a larger capacity of mind could develop was conscience: "I say grant reason to any animal with social \& sexual instincts \& yet with passion he must have conscience - this is capital view" (Darwin, Notebook M: 2-3). Conscience, especially troubled conscience, is then crucial for the development of the moral sense. Conscience "is supreme because it is a part of our nature which regulates our feelings steadily \& not like an appetite \& passion, which receive enjoyment from gratification \& hence are forgotten" (Darwin, Notebook M: 77). Moreover it can be "improved by attending \& reasoning on its action, \& on the results following our conduct" (Darwin, Notebook M: 77). Thus, for Darwin, man cannot avoid reflection, as past impressions and images are constantly passing through his mind. If man gratifies selfish desires, he will judge them by the ever-enduring social instinct and by his deep regard for the opinion of his fellows. He will then feel remorse, repentance, regret, or shame and, as a consequence, he will resolve more or less firmly to act differently in the future. Conscience is thus the ability to look backward and to serve as a guide to the future.

However, Darwin had not yet explained social instincts and the origin of the moral sense of man according to the mechanism of natural selection. This was a crucial problem that he needed to address in order to provide an evolutionary account of ethics. The problem was that if natural selection operated for the benefit of the individual, expressing certain traits, how could it explain the acquisition of qualities that not only failed to confer direct 
advantage on their bearers but might even be harmful for them? Darwin's solution to this problem was the nowadays controversial concept of group selection which he first applied to social insects in the Origin of Species (Darwin, 1859: 236) and to the human animal in the Descent of Man (1871):

"It must not be forgotten that although a high standard of morality gives but a slight or no advantage to each individual man and his children over the other men of the same tribe, yet that an advancement in the standard of morality and an increase in the number of well-endowed men will certainly give an immense advantage to one tribe over another. There can be no doubt that a tribe including many members who, from possessing in a high degree the spirit of patriotism, fidelity, obedience, courage, and sympathy, were always ready to give aid to each other and to sacrifice themselves for the common good, would be victorious over most other tribes; and this would be natural selection. At all times throughout the world tribes have supplanted other tribes; and as morality is one element in their success, the standard of morality and the number of well-endowed men will thus everywhere tend to rise and increase" (Darwin, 1871: 166).

It was in this work on human evolution that Darwin recovered and developed his original ideas on the moral sense of man. The acquisition of this distinctive trait between man and the lower animals would involve four overlapping steps: First, the development of social instincts that provide services and feelings to the members of the same group. Second, the development of mental faculties to recall a social instinct that might momentarily have been swamped by strong instinct desires. Third, the development of language in order to codify guides to action and to communicate the needs of other members of society. Fourth, the development of habits in the individuals of the group, since social instincts and impulses would be greatly strengthened by habit, as would obedience to the wishes and judgment of the community (Darwin, 1871: 72-73).

Finally, for Darwin the true foundation of morality was not the "greatest happiness principle" that was at the core of utilitarian theories of ethics, but the "the general good or welfare of the community". By "general good", he understood "the means by which the greatest possible number of individuals can be reared in full vigour and health, with all their faculties perfect, under the conditions to which they are exposed" (Darwin, 1871: 98). Darwin thought that in this way, his ethical theory overturned utilitarianism. 
It took a long time for Darwin to develop and publish his ideas on the moral sense. However, his notebooks testify to the fact that, from an early stage, he was eager to provide a portrait of man as a compassionate and benevolent animal.

\section{Post Scriptum}

Darwin's optimistic view of the role of morality in the evolution of man was not shared by most of his friends and contemporaries (Farber, 1994: 58-78). Even before the publication of The Descent of Man, Charles Lyell expounded his great difficulties in envisaging that man's intellect and moral sensibility could have evolved from animal ancestors (Richards, 1987: 200-206). Similarly, after his conversion to spiritualism, Alfred Russell Wallace, the co-discoverer of evolution by natural selection, conceded that "benevolence and honesty might have aided the tribe whose members practiced these virtues", but natural selection could not explain "the peculiar sanctity attached to actions which each tribe considers right and moral" (Wallace, 1870: 199). Even the most tenacious advocate of the theory of evolution, Thomas Henry Huxley differed from Darwin. In his book Evolution and Ethics (1893), he pointed out that if the process of evolution is responsible for the origin of moral sentiments, the same would be applicable to the origin of the immoral sentiments. He remarked that "the thief and the murderer follow nature just as much as the philanthropist. Cosmic evolution may teach us how the good and the evil tendencies of man may have come about; but, in itself, it is incompetent to furnish any better reason why what we call good is preferable to what we call evil than we had before" (Huxley, 1893: 66).

Evolutionary ethics, especially Spencerian ethics, sustained severe criticism in the first half of the twentieth century. At the level of directives, they proposed and promoted problematic programs ranging from right-wing capitalism to the social policies of the fascist countries in the 1930's. At the level of philosophical justification, they were accused of the grossest technical mistakes in not taking into account David Hume's distinction between matters of fact and matters of value (the is/ought dichotomy) (Ruse, 2004: 27). This problem was emphatically laid out by the English philosopher G. E. Moore and labeled by him the "naturalistic fallacy".

In recent years, there has been a growing interest in approaches that attempt to link morality with evolutionary biology. The most prominent figure 
in the field is probably the sociobiologist Edward O. Wilson who declared that "the time has come for ethics to be removed temporarily from the hands of philosophers and biologicized" because "ethical precepts are reached by consensus under the guidance of the innate rules of mental development" (Wilson, 1975: 562; 1998: 275). A relatively significant number of biologists and philosophers of biology have attempted to provide evolutionary ethical approaches while attempting to avoid the "naturalistic fallacy" (illustrative examples are Ruse, 1986; Arnhart, 1998; Rolston, 1999). The field has also been given a new momentum by recent scientific discoveries that suggest that morality has a neurobiological basis (Arnhart, 1998: 69-87; Hotz, 2007). New expectations in evolutionary ethics have also been stressed by philosophers such as Alex Rosenberg who argue that the Darwinian theory is progressively contributing to an understanding of morality, "how nature may have selected both for cooperative norms and for the emotions that express a commitment to these norms" (Rosenberg, 2003: 331). Then, it might not be possible to completely isolate the theoretical considerations of ethics from the biological instincts that shape human nature.

\section{Bibliographic references}

Arnhart, L. 1998. Darwinian Natural Right: The Biological Ethics of Human Nature. New York, State University of New York Press.

Browne, J. 1995. Charles Darwin: Voyaging, Volume I of a Biography. London, Pimlico.

Browne, J. 2002. Charles Darwin: The Power of Place, Volume II of a Biography. London, Pimlico.

Darwin, C. Notebook M, MS. [Online]. Cambridge, Cambridge University Library. [Consultado em 15-01-2010]. Disponível em: http://darwin-online.org.uk/ content/frameset?itemID=CUL-DAR125.-\&viewtype=text\&pageseq=1.

Darwin, C. Old and Useless Notes about the Moral Sense \& Some Metaphysical Points, MS. [Online]. Cambridge, Cambridge University Library. [Consultado em 11-01-2010]. Disponível em:

http://darwin-online.org.uk/content/frameset?viewtype=text\&itemID=CULDAR91.4-55\&pageseq $=1$.

Darwin, C. Notebook N, MS. [Online]. Cambridge, Cambridge University Library. [Consultado em 16-01-2010]. Disponível em: http://darwin-online.org.uk/ content/frameset?itemID=CUL-DAR126.- viewtype=text\&pageseq=1. 
Darwin, C. 1859. The Origin of Species. London, John Murray.

Darwin, C. 1871. The Descent of Man. London, John Murray.

Darwin, C. 1887. The life and letters of Charles Darwin, including an autobiographical chapter. In: Darwin, F. (ed.) The life and letters of Charles Darwin, including an autobiographical chapter. Volume 1. London, John Murray.

Darwin, C. 1933. Charles Darwin's Diary of the Voyage of H. M. S. Beagle. In: Barlow, N. (ed.) Charles Darwin's Diary of the Voyage of H. M. S. Beagle. Cambridge, Cambridge University Press.

Desmond, A.; Moore, J. 2010. Darwin's Sacred Cause: Race, Slavery and the Quest for Human Origins. London, Penguin Books.

Farber, P. L. 1994. The Temptations of Evolutionary Ethics. Berkeley, University of California Press.

Hotz, R. L. 2007. Scientists draw link between morality and brain's wiring. [Online]. Washington, The Richard Dawkins Foundation for Reason and Science. Disponível em: http://richarddawkins.net/articles/1136.

Huxley, T. H. 1893. Evolution and Ethics and Other Essays. London, MacMillan.

Mackintosh, J. 1862. Dissertation on the Progress of Ethical Philosophy Chiefly during the Seventeenth and Eighteenth Centuries. Edinburg, Adam and Charles Black, $3^{\text {rd }}$ edition.

Richards, R. J. 1987. Darwin and the Emergence of Evolutionary Theories of Mind and Behaviour. Chicago, The University of Chicago Press.

Rolston, Holmes III. 1999. Genes, Genesis, and God: Values and Their Origins in Natural and Human History. Cambridge, Cambridge University Press.

Rosenberg, A. 2003. Darwinism in Moral Philosophy and Social Theory. In: J. Hodge; G. Radick (eds.) The Cambridge Companion to Darwin. Cambridge, Cambridge University Press: 310-332.

Ruse, M. 1986, Taking Darwin Seriously: A Naturalistic Approach to Philosophy. Oxford, Blackwell.

Ruse, M. 2004. “Evolutionary Ethics Past and Present”. In: Clayton, P.; Scholoss, J. (eds.) Evolution and Ethics: Human Morality in Biological and Religious Perspective. Cambridge, Wm. B. Eerdmans Publishing Co.

Wallace, A. R. 1870. Contributions to the Theory of Natural Selection. London, Macmilan. Wilson, E. O. 1975. Sociobiology: The New Synthesis. Harvard, Belknap Press.

Wilson, E. O. 1998. Consilience. London, Little, Brown and Company.

Artigo recebido a 18 de Fevereiro de 2010 e aceite a 7 de Junho de 2010. 